\title{
Investigation of geological features and economical potential of commercial marble around Yarışlı lake, Burdur (SWTurkey)
}

\author{
Muhammet Yılmaz $^{\mathrm{a}, *}$, Şemsettin Caran ${ }^{\mathrm{a}}$ \\ a Süleyman Demirel University, Department of Geological Engineering, TR-32260, Isparta
}

\begin{tabular}{l} 
A R T I C L E I N F O \\
\hline Article history: \\
Received 15 May 2019 \\
Received in revised form 15 June 2019 \\
Accepted 18 June 2019 \\
\hline Keywords: \\
Yarışlı Lake \\
Commercial marble \\
Dutdere Limestone \\
Burdur
\end{tabular}

\begin{abstract}
A B S T RACT
Limestones, travertines and dolomites are sedimentary rocks. In marble sector, these carbonate rocks can be named as commercial marbles in addition to the geological marbles. Despite the huge reserves of carbonate rocks in Turkey, there is a limited amount of carbonate reserves that have the desired properties preferred by the marble sector. Tauride belt in the southern Turkey has one of the important parts of these reserves. This study has focused on the geological features of commercial sedimentary marbles represented by dolomite and limestone deposits around Yarışlı Lake and evaluation of their economical potential. The Dutdere Limestone occuring within the Lycian nappes is observed around the Yarışlı Lake and have a special color and texture which are very desirable in marble industry. The limestones, known as "Sandia" marble, are the only current source for lightning texture in the marble industry. In this area, there is also a type of marble named as "Bayulan" marble with smoot cream beige color that have industrial marble potential.
\end{abstract}

(C) 2019. Turkish Journal Park Academic. All rights reserved.

\section{Introduction}

Marble has two different definitions such as scientific and commercial marble. In scientific usage, marble is defined as metamorphosed carbonate rocks (e.g.limestone or dolomite). However, commercial marble is any crystalline rock which could be cut and capable of being polished. For an economic marble, rocks should yield required block size suitable for sale and take a polish etc. Igneous rocks (granite, syenite, basalt, andesite, serpentinite, norite), sedimentary rocks (limestone, travertine, dolomite, sandstone, conglomerate), and metamorphic rocks (metamorphosed dolostone and limestone) can be in commercial marble classification. Marble sector is progressing in the way of being one of the most important sector in Turkey, whilst Burdur region has an important contribution for the marble production and economic income.

The study area occurs in the southwest of Burdur lake within the Lycian (Teke) nappesin the southwestern Turkey (Fig. 1,2). In this study, it is aimed to investigate geological properties and economic potential of the commercial marbles around Yarışlı lake (Burdur).

\section{Material and Methods}

Field studies in the studied area was carried out between 2015 and 2016. 1/100 000 scale geological map of the study area was prepared using literature.

\section{Results}

\section{Geology of the study area}

The study area is located in the south west of Burdurlake and covers an area around the Yarışl lake (Fig. 1). In the study area, allochthonous and autocthonous rock units are found(Fig. 2,3). Allochthonous units form the basement of the study area and can be separated into Marmaris Peridotite(Kmo), Kızılcadağ Melange (Kkzm) and Olistostrome, Orhaniye Formation(JKo), Dutdere Limestone (TRJd) (Şenel et al., 1987). Tertiary aged Mamatlar Formation (Tpm), Çameli Formation (Plç) and recent alluvial deposits rest unconformably over the Lycian nappes. 


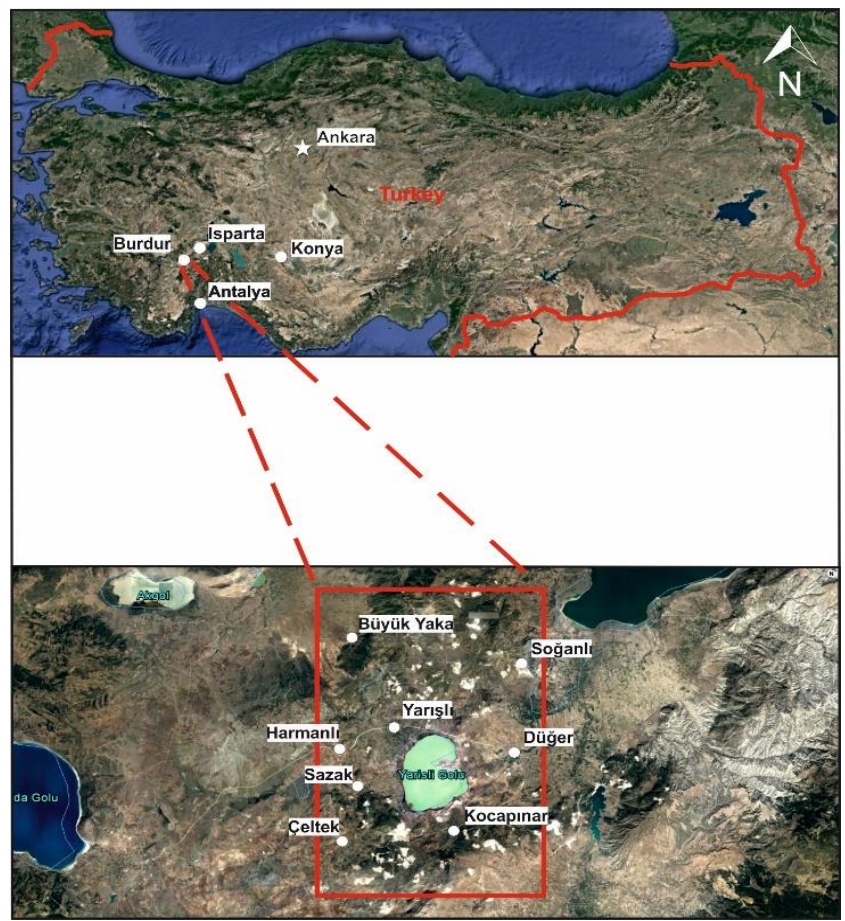

Figure 1. Location map showing some marble localities in the study area (google earth view, patchy irregular white areas)

Marmaris peridotite is composed dominantly of ultramafic rocks, in places, in the composition of serpentinized harzburgite and dunite. Ultramafic rocks display mainly serpentine veins including asbestos veinlets in some shear zones and brecciated structure due to emplacement-related tectonic activities.

Kızlcadağ melange and olistostrome includes blocks of different ages and origin such as serpentinized harzburgite, dunite, diabase, basic volcanic rocks, neritic and pelagic limestones, clastic sediments, radiolarite-chert, dolomite within the sheared serpentinite matrix.

Jurassic-Cretaceous aged Orhaniye Formation is composed of micritic and chert-bearing limestones interlayered with mafic volcanic rcosk, radolarite-chert assemblages and shale (Şenel et al.,1989).

Middle Triassic-Liassic aged Dutdere Limestone consists mainly of recrystallized, massive limestone (Fig. 4), chertbearing limestones and occurs especially at the upper most part of the Lycian nappes. They outcrop in the north and south of Yarışlı lake in the study area.

Montian-Thanetian aged Mamatlar Formation consists of algal limestones and outcrops in the east and southwest of the study area (Șenel et al., 1989). Limestons are mainly massive, thickbedded, lightbrown, yellowish brown, grey, beige colored and in places interlayered with silty-sandy limestones.

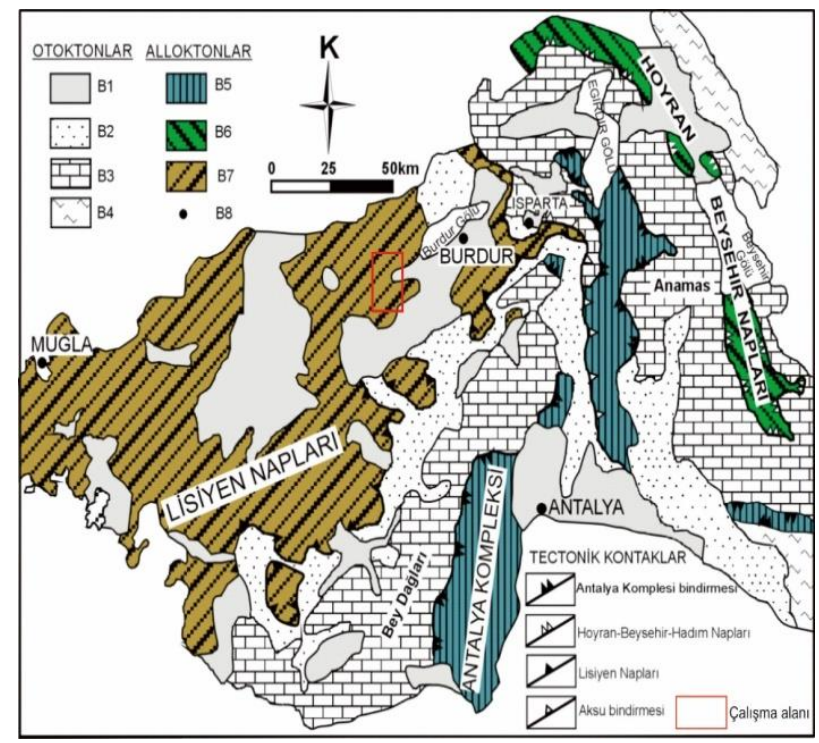

Figure 2. Simplified geologic map of the Isparta Angle(modified from MTA 1/500000 scale geological map of Turkey (Alpan et al.,1964). B1: Plio-Quaternary terrestrial deposits, B2-B3: Beydağları autochthonous (B2: Tertiary clastic series, B3: Mesozoic-Tertiary Tauride carbonate platform), B4: Metamorphic series, B5: Antalya Nappes, B6: Hoyran-Beyşehir-Hadım Nappes, B7:ycian (Teke) Nappes: B8:city centrum.

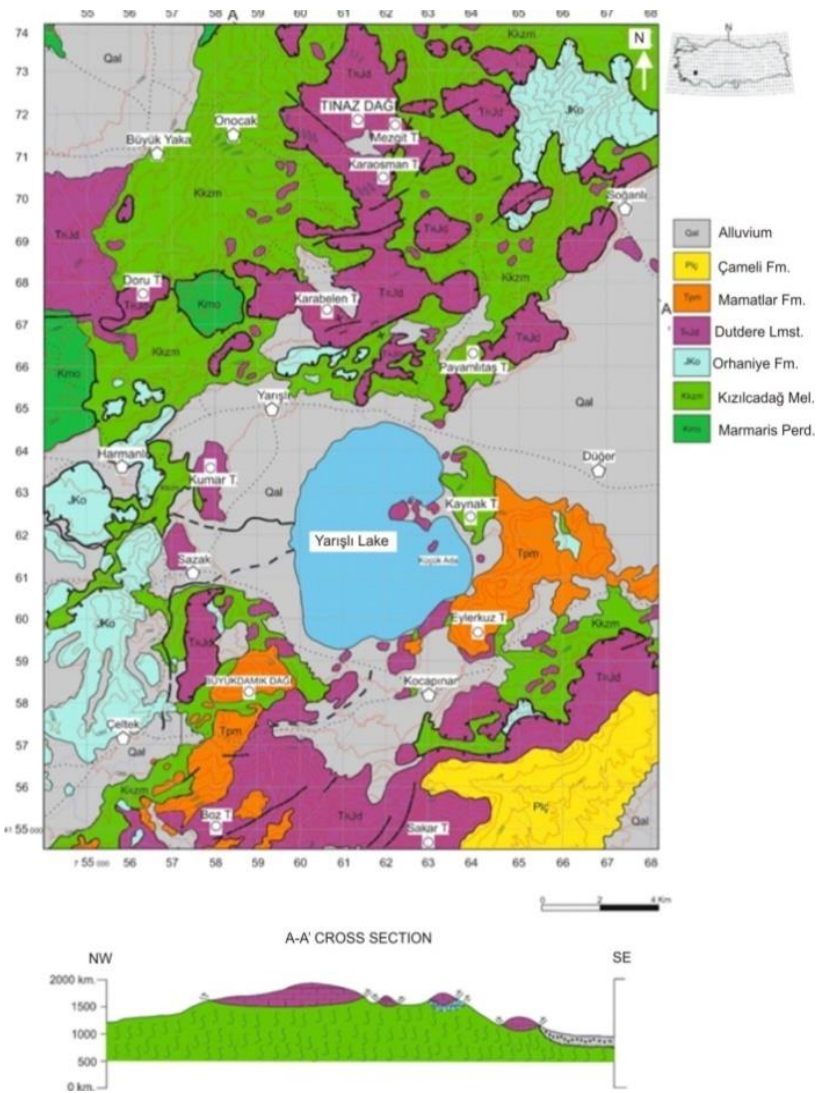

Figure 3. Geologic map and cross-section of Yarışlı lake (modified from geologic map of MTA, 1/100 000 scale M23 quadrangle). 


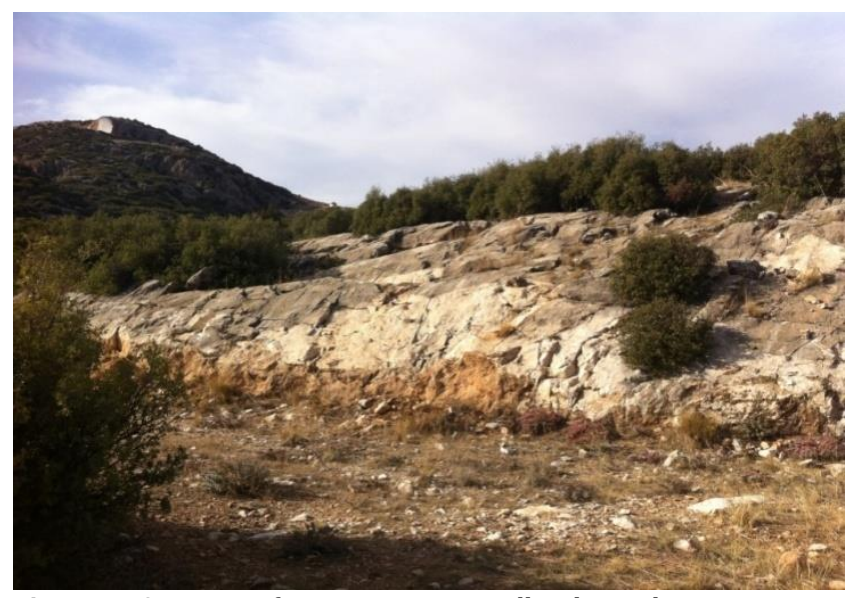

Figure4. Outcrop of massive, recrystallized Dutdere Limostone exploited for commercial marble

Çameli Formation (or Burdur Formation) is characterized mainly by lacustrine deposits including thin to thick bedded, white, light grey, green colored marl, claystone, sandstone, coarse-grained sandstone. In places, tuff and tuffite interlayers are observed in this formation. Initiation of deposition of the Çameli Formation is interpreted to began at the Upper Miocene (Erakman et al., 1982; Yalçınkaya et al., 1986). Çameli Formation ovlerlies unconformably the Teke nappes and overlain unconformably by the recent alluvial deposits.

\section{Marble potential of the Yarışlı region}

Based on economic value, rocks are evaluated according to the following criteria: color, strength, homogeneity, durability, number of cracks and blemishes. Limestones quarried for economic natural stone around Burdur has a color of beige, cream beige, so-called Burdur Beige. Of these, Burdur Beige is a reference beige marble from Turkey and a type of natural stone with considerable demand both on the Turkish and international markets. After the year 2000's, marble sector began to develop in the district of Burdur. The studied area has an economic potential interms of marble production. Commercial marbles are extracted from the Dutdere Limestone occurring mainly over the Domuzdağı nappe(Fig. 4, 5). Beige and crem beige colored limestones exploited as commercial natural stone are more preferred than reddish carbonates (limestones). In the study area, there are 135 marble licence area by the year 2016. 17 of these quarries were left, 15 of the licences were cancelled, exploitations of 16 licence areas were ended. 40 licence areas were on tender. Currently, there are 45 exploitations. These marble quarries are on the Dutdere Limestone and marble quarries around Yarışlı lake can be observed on almost all the hills(Fig. 5). However, some of the quarries are deserted due to geological problems or market situations. The study area has an important marble reserves in terms of Sandia and Bayulan type marbles (limestone) production, and these marbles are of typical with white-cream in coloured (Figs. 6,7). There are favorable features such as beige, cream beige color, beatiful appearance, reserve, thick bedding or massive structures, enough extension for marble production. Thickness of the formation from which marble extracted ranges from 50 to 700 meters (av. $200 \mathrm{~m}$ ).

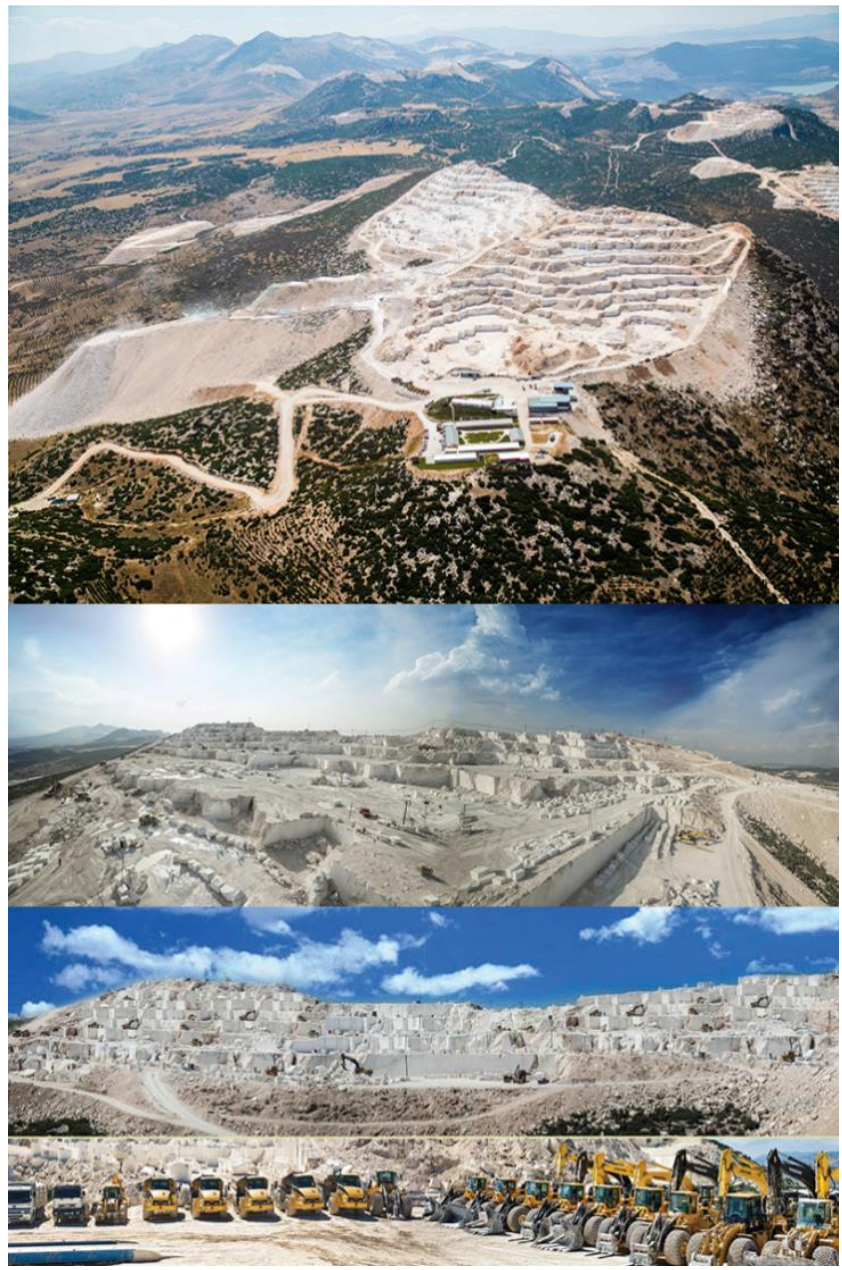

Figure 5. View of marble quarries on the Dutdere Limestone

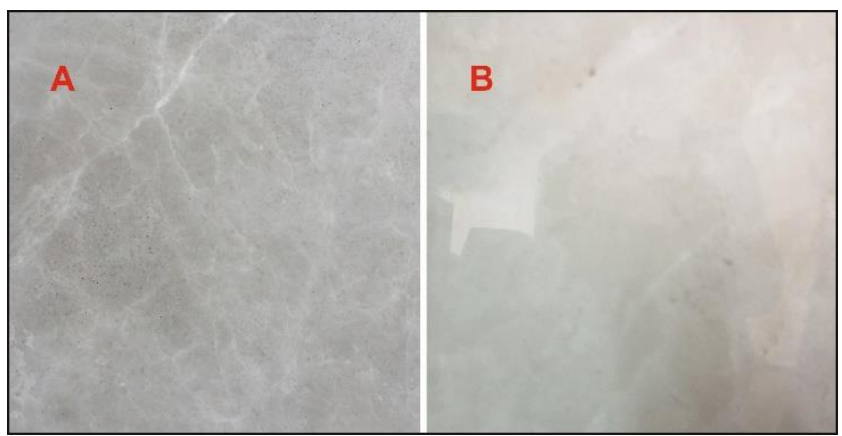

Figure 6. a) Polished surface view of Sandian marble and b) Bayulan marble

Limestones are mainly massive and color may change laterally. However, tectonism affected the allochthonous Dutdere Limestone within the Lyciannappes during nappe emplacement giving rise to fracture formation. The most important disadvantage of the formation is undesired fracture for marble production. 


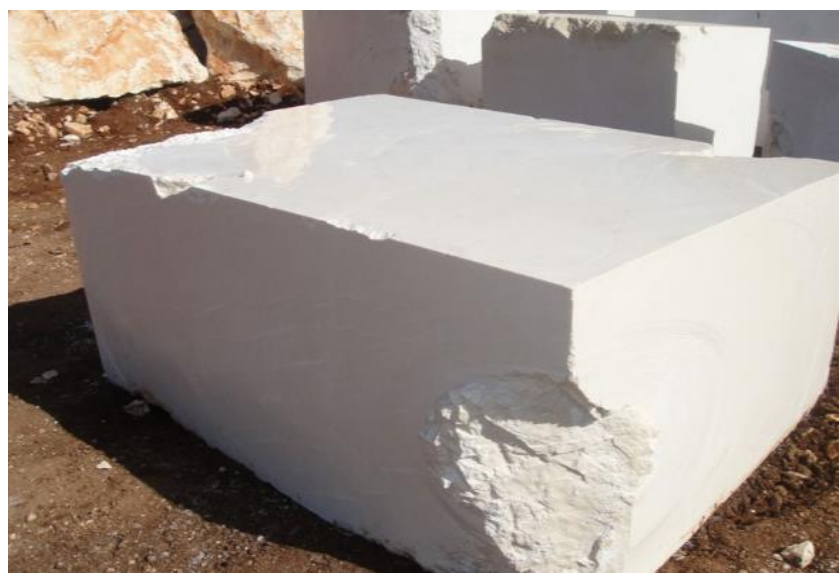

Figure 7.View of a marble block from Bayulanquarry

Limestones from which economic marbles were extracted cover an area of $70 \mathrm{~km}^{2}$. One tenth of these outcrops are used for marble production which is about $7 \mathrm{~km}^{2}$. Estimation of reserve is done taking into consideration 5 percent block yield. Thickness of the unit in the study area is about 100 meters. According to these data;

Volume : average outcrop area $\mathrm{x}$ average thickness

Volume $\quad: 7,000,000 \mathrm{~m}^{2} \times 100 \mathrm{~m}$

Probable geologic reserve : volume $\mathrm{x}$ density

Probable geologic reserve : 700,000,000 $\mathrm{m}^{3} \times 2.7$ tonnes $/ \mathrm{m}^{3}$

Probable geologic reserve : $1,890,000,000$ tonnes

As a result, $94,500,000$ tonnes $/ 700,000,000 \mathrm{~m}^{3}$ block marble can be produced from the study area by $\% 5$ yield.

\section{Results}

-This study was carried out in the vicinity of Yarışlılake (Burdur, SWTurkey).

-Allochthonous and autochthonous rock units are distributedin the study area. Allochthonous Lycian nappes form the basement of the study area and autochthonous Tertiary aged Mamatlar Formation and Burdur Formation consisting of lacustrine Neogene sediments overly uncomformably the Lyciannappes.

-The Dutdere Limestone of the Lyciannappes is exploited as a commercial marble. They are beige, cream beige colored, socalled Burdur Beige.

-Limestones from which economic marbles were extracted covers an area of $70 \mathrm{~km}^{2}$. One tenth of these outcrops are used for marble production which is about $7 \mathrm{~km}^{2}$. Probable marble reserve was estimated as 94,500,000 tonnes/700,000,000 $\mathrm{m}^{3}$ by $\% 5$ yield.

-In the study area, there were 135 marble licence areas by the year 2016. However, currently, there are 45 exploitations.

\section{References}

Alpan, S., Pamir, H.N., Erentöz, C., $\quad$ 1964.1/500000 ÖlçekliTürkiyeJeolojiHaritası. MTA, Ankara

Erakman, M., Meşhur, M., Gül, M.A., Alşkan, H., Öztas, Y. veAkpınar, M., 1982, Fethiye- Köyceğiz-TefenniKalkanarasındakalanalanınjeolojisi.TürkiyeAltıncı Petrol Kong Teb.,Nisan-1982, Ankara, 23-31.

Şenel, M., Selçuk, H., Bilgin, Z.R., Şen, A.M., Karaman, T., Erkan,

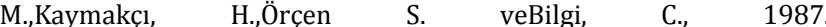
Likyanaplarıöncepheözellikleri.TürkiyeJeol.KurultayıBildiriÖzleri, 8.

Şenel, M., Selçuk, H., Bilgin, Z.R., Şen, M.A., Karaman, T., Dincer, M.A. Durukan, E., Arbas, A., Örçen, S., Bilgi, C., 1989.Çameli (Denizli) Yeşilova (Burdur) - Elmalı (Antalya) vedolayınınjeolojisi. MTA Rap.9429 Ankara (Yayınlanmamış).

Yalçınkaya, S., Engin, A., Afşar, Ö.P. veTaner, K., 1986.BatıToroslarınJeolojisi,Ispartaprojesiraporu. MadenTetkikveAramaGenelMüdürlüğüraporları (yayınlanmamış), Ankara. 